OPEN ACCESS

Edited by:

Clinton Mathias,

Western New England University,

United States

Reviewed by:

Karin Loser,

University of Münster, Germany

Daniel Conrad,

Virginia Commonwealth University,

United States

*Correspondence:

Rudolf Valenta

rudolf.valenta@meduniwien.ac.at

Specialty section:

This article was submitted to Immunological Tolerance and

Regulation,

a section of the journal

Frontiers in Immunology

Received: 27 September 2018 Accepted: 18 December 2018

Published: 17 January 2019

Citation:

Eckl-Dorna J, Villazala-Merino S, Linhart B, Karaulov AV, Zhernov Y, Khaitov $M$, Niederberger-Leppin $V$ and

Valenta $R$ (2019) Allergen-Specific

Antibodies Regulate Secondary

Allergen-Specific Immune Responses.

Front. Immunol. 9:3131.

doi: 10.3389/fimmu.2018.03131

\section{Allergen-Specific Antibodies Regulate Secondary Allergen-Specific Immune Responses}

\author{
Julia Eckl-Dorna ${ }^{1}$, Sergio Villazala-Merino ${ }^{1}$, Birgit Linhart ${ }^{2}$, Alexander V. Karaulov ${ }^{3}$, \\ Yury Zhernov ${ }^{4}$, Musa Khaitov ${ }^{4}$, Verena Niederberger-Leppin ${ }^{1}$ and Rudolf Valenta ${ }^{2,3,4 *}$ \\ ${ }^{1}$ Department of Otorhinolaryngology, Medical University of Vienna, Vienna, Austria, ${ }^{2}$ Division of Immunopathology, \\ Department of Pathophysiology and Allergy Research, Center for Pathophysiology, Infectiology and Immunology, Medical \\ University of Vienna, Vienna, Austria, ${ }^{3}$ Laboratory of Immunopathology, Department of Clinical Immunology and Allergy, \\ Sechenov First Moscow State Medical University, Moscow, Russia, ${ }^{4}$ NRC Institute of Immunology FMBA of Russia, Moscow, \\ Russia
}

Immunoglobulin E (IgE)-associated allergy is the most common immunologically-mediated hypersensensitivity disease. It is based on the production of IgE antibodies and T cell responses against per se innocuous antigens (i.e., allergens) and subsequent allergen-induced inflammation in genetically pre-disposed individuals. While allergen exposure in sensitized subjects mainly boosts lgE production and $T$ cell activation, successful allergen-specific immunotherapy (AIT) induces the production of allergen-specific IgG antibodies and reduces T cell activity. Under both circumstances, the resulting allergen-antibody complexes play a major role in modulating secondary allergen-specific immune responses: Allergen-lgE complexes induce mast cell and basophil activation and perpetuate allergen-specific $T$ cell responses via presentation of allergen by allergen presenting cells to T cells, a process called IgE-facilitated antigen presentation (FAP). In addition, they may induce activation of IgE memory B cells. Allergen-induced production of specific IgGs usually exerts ameliorating effects but under certain circumstances may also contribute to exacerbation. Allergen-specific IgG antibodies induced by AIT which compete with IgE for allergen binding (i.e., blocking lgG) inhibit formation of lgE-allergen complexes and reduce activation of effector cells, $\mathrm{B}$ cells and indirectly $\mathrm{T}$ cells as FAP is prevented. Experimental data provide evidence that by binding of allergen-specific IgG to epitopes different from those recognized by IgE, allergen-specific IgG may enhance lgE-mediated activation of mast cells, basophils and allergen-specific $\operatorname{lgE}^{+} \mathrm{B}$ cells. In this review we provide an overview about the role of allergen-specific antibodies in regulating secondary allergen-specific immune responses.

Keywords: allergy, allergen, antibody, facilitated allergen presentation (FAP), T cell response, allergen-specific immunotherapy, super-crosslinking, $\operatorname{lgE}^{+}$memory $B$ cell 


\section{BACKGROUND}

Approximately $30 \%$ of the world population suffer from immunoglobulin E ( $\mathrm{IgE}$ )-associated allergy, the most common hypersensitivity disease. Besides environmental factors also genetic factors are very important for the development of IgE responses. They include genetic factors promoting Th2 immune responses and IgE production in general as well as genetic restriction of allergen-specific immune responses (1-3). Allergic patients suffer from a broad variety of symptoms such as rhinoconjunctivitis, asthma, skin inflammation, gastrointestinal symptoms, and life-threatening allergic shock. Allergen-specific antibodies play a major role in development, maintenance, and treatment of allergic diseases $(3,4)$. During early-phase responses to allergen encounter, crosslinking of surface receptor bound IgE on mast cells and basophils by its cognate allergen induces activation of these cells (5). This signaling cascade finally results in mediator release causing symptoms of the immediate inflammatory responses. Despite its prominent role in mediating early effector cell activation, IgE may also contribute to late phase reactions in allergy. Antigen presenting cells (APCs) can bind and internalize allergen-IgE complexes via IgE receptors and thereby enhance allergen-specific $\mathrm{T}$ cell activation (6). The latter role of $\mathrm{IgE}$ in regulating $\mathrm{T}$ cell responses is supported not only by in vitro experiments but also by the observation that anti-IgE treatment alleviates late phase reactions in allergic asthmatic patients (7). The effect of treatment-induced reduction of IgE-meditated T cell activation (7) may also act in concert with a decrease in mast cell/basophil activation (8) and associated reduced release of inflammatory cytokines $(9,10)$ leading to an amelioration in late phase reactions upon anti-IgE treatment.

So far, allergen-specific immunotherapy (AIT) is the only disease-modifying treatment in allergy with long lasting clinical effects and modulation of the allergic immune response $(11,12)$. The mechanisms by which AIT effectively reduces allergic inflammation includes changes in cellular as well as humoral responses to allergen contact (13-16). One cardinal feature of successful AIT is the induction of allergen-specific IgG production. In AIT treated patients, a rise in allergenspecific $\mathrm{IgG}$, of the $\mathrm{IgG}_{4}$ and $\mathrm{IgG}_{1}$ subclass, is observed both in serum (17-19) as well as locally for example in nasal secretions $(20,21)$. AIT-induced allergen specific IgG4 antibodies have received particular attention because they seem to be responsible for the sustained effects of this treatment (22). Though $\operatorname{IgG}_{4}$ accounts for only $4 \%$ of total IgG in healthy individuals, it can represent up to $75 \%$ of total IgG in subjects undergoing allergen immunotherapy (23). Importantly,

\footnotetext{
Abbreviations: Ab, antibody; APC, antigen presenting cell; BCR, B cell receptor; $\mathrm{B}_{\mathrm{R}} 1$, B regulatory cell 1 ; CD, cluster of differentiation; $F A B$, facilitated antigen binding; FAP, facilitated antigen presentation; HIV, human immunodeficiency virus; AIDS, acquired immunodeficiency syndrome; Ig, immunoglobulin; IL, interleukin; SCIT, subcutaneous immunotherapy; AIT, allergen-specific immunotherapy; SLIT, sublingual immunotherapy FAB, facilitated antigen binding; FAP, facilitated antigen presentation; LPP: Lolium perenne peptide; DnaK: prokaryotic heat shock protein; m, month; N.A., not applicable; Oma, Omalizumab; SAR, seasonal allergic rhinitis; s.c., subcutaneous; SCIT, subcutaneous immunotherapy; SLIT, sublingual immunotherapy; SIT, specific immunotherapy; SMS, symptom medication score; WD, withdrawal; y, year.
}

allergen- $\mathrm{IgG}_{4}$ immune complexes are non-inflammatory because $\mathrm{IgG}_{4}$ does not activate complement. Moreover, it has been suggested that $\operatorname{IgG}_{4}$ can form bispecific and functionally monovalent antibodies by exchange of Fab arms under certain conditions $(24,25)$. Ideally, IgGs induced during AIT are induced to block the binding of IgE to the allergen either by occupying IgE epitopes or parts thereof and/or by steric hindrance. They compete with IgE for the binding to the allergen and are thus termed "blocking antibodies" $(4,26)$. By blocking binding of IgE to the allergen, they may on the one hand inhibit boosting of IgE production by B cells as well as mast cell and basophil activation but they can also block the presentation of allergen by IgE-mediated allergen presentation to T cells $(13,27)$.

\section{ROLE OF ALLERGEN-SPECIFIC ANTIBODIES IN THE NATURAL COURSE OF THE DISEASE}

Already in 1903, long before allergy was recognized as an immunologically-mediated hypersensitivity disease, Dunbar demonstrated that allergic reactions in patients could be ameliorated when the disease-causing allergens were neutralized with an allergen-specific antiserum (28) (Figure 1). IgE was identified as a new class of immunoglobulins responsible for allergic reactions in 1966 (29) and became detectable in blood by serology in 1967 (30). In the same year, Levy and Osler reported that the "reagenic reactivity" mediated by $\operatorname{IgE}$ in serum of ragweed pollen allergic patients as measured by passive leukocyte sensitivity was lowest before the ragweed season and highest after the season during the autumn months (31) (Figure 1). Later, the reagenic activity was attributed to allergen-specific IgE and rises in allergen-specific serum IgE levels were measured after allergen exposure $(32,33)$.

Receptor bound IgE can persist on mast cells in tissues for weeks if not months (34). This is supported by the fact that non-allergic recipients of solid organ transplants can exhibit allergic reactions mediated by mast cell-fixed $\operatorname{IgE}$ transferred from an allergic donors months after the transplantation (35). Furthermore, anti-IgE treatment has an immediate effect on free IgE levels, but downregulation of high affinity receptors of $\operatorname{IgE}$ takes several weeks indicating long survival of IgE in a receptor bound form (36). In contrast free serum IgE has a rather short half-life of $2-3$ days $(37,38)$ and needs to be replenished constantly to sustain allergen-specific IgE levels also in the absence of allergenic stimulation. The mechanisms underlying secondary allergen-specific IgE responses as well as the existence of memory $\operatorname{IgE}^{+} \mathrm{B}$ cells and long-lived IgE plasma cells in human subjects are still debated $(3,39)$. Some studies employing flow cytometry suggest existence of both $\mathrm{IgE}^{+}$memory B cell as well as plasma cells in the blood (4043). However it needs to be borne in mind that in these flow cytometric analyses co-staining for the low affinity receptor for IgE, CD23, that is known to be expressed both on naive as well as on memory B cells, albeit at a lower level, (44) and to bind IgE, was not performed. Another limitation is that only the minority of IgE is produced in the blood (45) and that the 
1903

1935

1940

1967

1968

1982

1991

1993

1999

2003-

2006

2003

2016

2018

2018

Dunbar et al.: Demonstration that antisera specific for pollen antigens ("toxins") can protect against allergic inflammation (23)

Cooke et al.: First demonstration that specific immunotherapy leads to production of "immune antibodies" preventing the allergen to react with the sensitized cell (75)

Loveless: Demonstration that there are two different antibodies to the allergen: the heat sensitive "atopic reagin" and the thermostable "inhibiting antibody" neutralizing the allergen (21)

Levy and Osler: Seasonal changes in passive leukocyte activity upon addition of patient serum diminish upon therapeutic immunization (26)

Lichtenstein et al.: Blocking of histamine release by leukocytes upon allergen challenge is mediated by antibodies of the IgG subclass (76)

Gleich et al.: Suppression of seasonal IgE rise by immunotherapy with short ragweed extract (84)

Iliopoulos et al.: Immunotherapy with ragweed extract reduces late phase skin and nose reactions accompanied by an increase in allergen-specific IgG levels (95)

Van der Heijden et al.: First demonstration of facilitated allergen presentation (FAP) in a CD23 expressing EBV B cell line (4)

Van Neerven et al.: Inhibition of FAP by blocking $\mathrm{IgG}$ antibodies induced by immunotherapy with birch pollen extract (22)

Mothes et al., Niederberger et al., Creticos et al.: Blunting of seasonal rise in allergen-specific $\mathrm{IgE}$ with novel vaccination strategies (grass pollen vaccine adjuvanted with monophosphoryl lipid $\mathrm{A}$, hypoallergenic derivatives of Bet $\mathrm{v} 1$ and a Ragweed-Toll-Like Receptor 9 agonist vaccine) $(79,88,87)$

Wachholz et al.: Allergen-specific IgG induced by grass pollen extract immunotherapy is relevant for blocking IgE-allergen complex binding to CD23 (102)

Zieglmayer et al.: The recombinant B cell epitope-based grass vaccine BM32 induces blocking IgGs and suppresses allergen-specific T cell proliferation (78)

Niederberger et al.: Vaccination with BM32 reduces seasonal increase in allergenspecific IgE levels (91)

Orengo et al.: Passive immunization with recombinant human cat-specific IgGs reduces early and late phase reactions in a nasal allergen challenge model (77)

FIGURE 1 | Timeline highlighting studies investigating the role of antibodies in regulating secondary immune responses. 
quest for IgE memory should probably be extended to other tissues bearing the environment for memory cell propagation and homing of plasma cells $(3,46)$. In this context, local $\operatorname{IgE}$ production has been observed in samples derived from nasal mucosa of atopic patients $(47,48)$. Indirect evidence for the existence of IgE memory comes from two major observations: Firstly atopic disposition was transferred by bone marrow transplantation and was still detectable 2 years afterwards (49). Secondly, patients undergoing controlled nasal provocation with defined amounts of recombinant allergens or extract clearly show a rise in allergen-specific IgE levels while allergen-specific IgG and IgM levels remained unchanged indicating the presence of $\mathrm{IgE}^{+}$memory $\mathrm{B}$ cells eventually residing in the nasal mucosa that can be activated upon nasal allergen contact $(33,50-$ 52).

Allergen-specific antibodies of the IgG class are present both in non-atopic as well as atopic subjects (53) but only a weak correlation between allergen-specific IgE and IgG responses has been observed (54). This divergence of $\operatorname{IgE}$ and IgG responses is already evident in early childhood suggesting that nonsequential class switch to IgE and IgG occurs independently $(55,56)$. While the $\operatorname{IgG}$ repertoire seems to be broader and starting with responses to foodborne molecules in early childhood, IgE is mostly directed to airborne molecules with a sequence and prevalence hierarchy. These findings indicate that $\operatorname{IgE}$ and $\operatorname{IgG}$ are raised toward different epitopes in atopic subjects. Whether allergen-specific IgG antibodies which recognize different epitopes on allergens than IgE antibodies and hence do not represent blocking IgG antibodies have functional roles in allergic patients is not well-investigated. It is however quite possible that the concurrent presence of allergen-specific polyclonal IgG in allergic patients may influence the secondary allergen-specific immune response at different levels as discussed below.

\section{Antibody-Mediated Facilitated Allergen Presentation to T Cells}

Different pathways and cell types can mediate the activation of allergen-specific $\mathrm{T}$ cells in the context of allergy. $\mathrm{T}$ cells can be activated by presentation of allergen by antigenpresenting cells (APCs) that has previously been internalized by fluid phase endocytosis (Figure 2A). However, in the context of allergy, receptor-mediated internalization of allergen- $\operatorname{IgE}$ complexes via high (Fc\&RI) affinity (Figure 2B) and low (CD23) affinity (Figure 2C) receptors for IgE by APCs- a process called facilitated antigen presentation (FAP) - has been shown to stimulate allergen-specific $\mathrm{T}$ cell proliferation more efficiently, in particular at low concentrations of allergen as they occur in vivo in allergic patients $(6,57-60)$. In this line, presentation via CD23-mediated FAP requires 100-1,000 times lower allergen concentration than presentation via fluid phase endocytosis (6, $57,61,62)$. In humans, high levels of CD23 are constitutively expressed mainly on naïve IgD + B cells (44) and have been described to bind both free and monomeric IgE as well as differently composed and sized IgE-allergen complexes (63). Surface density of $\mathrm{CD} 23$ on B cells positively correlates with total serum IgE levels and determines activation of allergenspecific T cells upon loading with IgE-allergen complexes (44). Though affinity is one factor driving complex formation of allergen with $\operatorname{IgE}$, clonality of the $\operatorname{IgE}$ repertoire is also an important factor in formation of complexes (64). The latter was especially important if IgE exhibited low to medium affinity for the allergen. While Fc\&RI-mediated internalization by dendritic cells seems to play a role in atopic dermatitis (59), CD23mediated FAP by non-cognate $\mathrm{B}$ cells is an important mechanism in driving allergic rhinitis $(44,57,65)$. The importance of CD23 in mediating allergen-presentation in the context of allergy is also supported by the fact that application of the anti-CD23 monoclonal antibody lumiliximab to allergen-stimulated PBMC cultures reduced their proliferation to allergen in vitro by $50 \%$ (66). In addition reduced IgE levels were observed upon antiCD23 treatment in cell culture models suggesting a potential role of $\mathrm{CD} 23$ in regulating IgE production (67). Furthermore, inhibition of FAP by immunotherapy induced IgG is one important mechanism for the reduction of allergen-specific $\mathrm{T}$ cell and cytokine responses during AIT (68) as discussed below in more detail.

\section{Possible Mechanisms by Which Polyclonal Allergen-Specific IgG May Augment Activation of Effector Cells as Well as $\operatorname{lgE}^{+}$ B Cell Receptor-Bearing B Cells}

The absolute requirement of cognate $\mathrm{T}$ cell help for boosting an established allergen-specific IgE response has been challenged by several recent findings. In mice, using oligomeric $\mathrm{B}$ cell epitope-derived peptides for immunization in the absence of any adjuvants, a boost in allergen-specific IgE responses in the absence of any detectable allergen-specific $\mathrm{T}$ cell response was observed (69). Furthermore, blockage of co-stimulation capable of inhibiting the primary allergic sensitization of mice had no effect on re-challenge in an already established allergen-specific immune response (70). But also various observations in human subjects suggest that secondary IgE responses may not necessarily require $\mathrm{T}$ cell help. In this respect, nasal challenge only with the $\mathrm{B}$ cell epitope-containing complete allergen but not with fragments of the major birch pollen allergen Bet $\mathrm{v} 1$ containing only $\mathrm{T}$ cell epitopes in the absence of B cell epitopes induced a relevant change of allergen-specific IgE levels (71). Interestingly, using a multicolour flow cytometry approach in combination with sequencing, the presence of two different $\operatorname{IgE}^{+}$memory B cell subsets was suggested (41): One population with high replication history and high somatic hypermutation frequency similar to memory cells derived from primary immune responses. The second population showed a limited replication history as well as low somatic hypermutation levels reminiscent of a germinal center independent response. Finally yet importantly, in patients undergoing long-term systemic high-dose therapy with cyclosporine-that is known to suppress $\mathrm{T}$ cell responsesIgE levels for inhaled allergens as well as kinetics upon seasonal allergen exposure were not impaired (72). In this line, a similar result was obtained in HIV infected patients (73): Despite severely compromised $\mathrm{CD} 4^{+}$cell counts, patients suffering from 

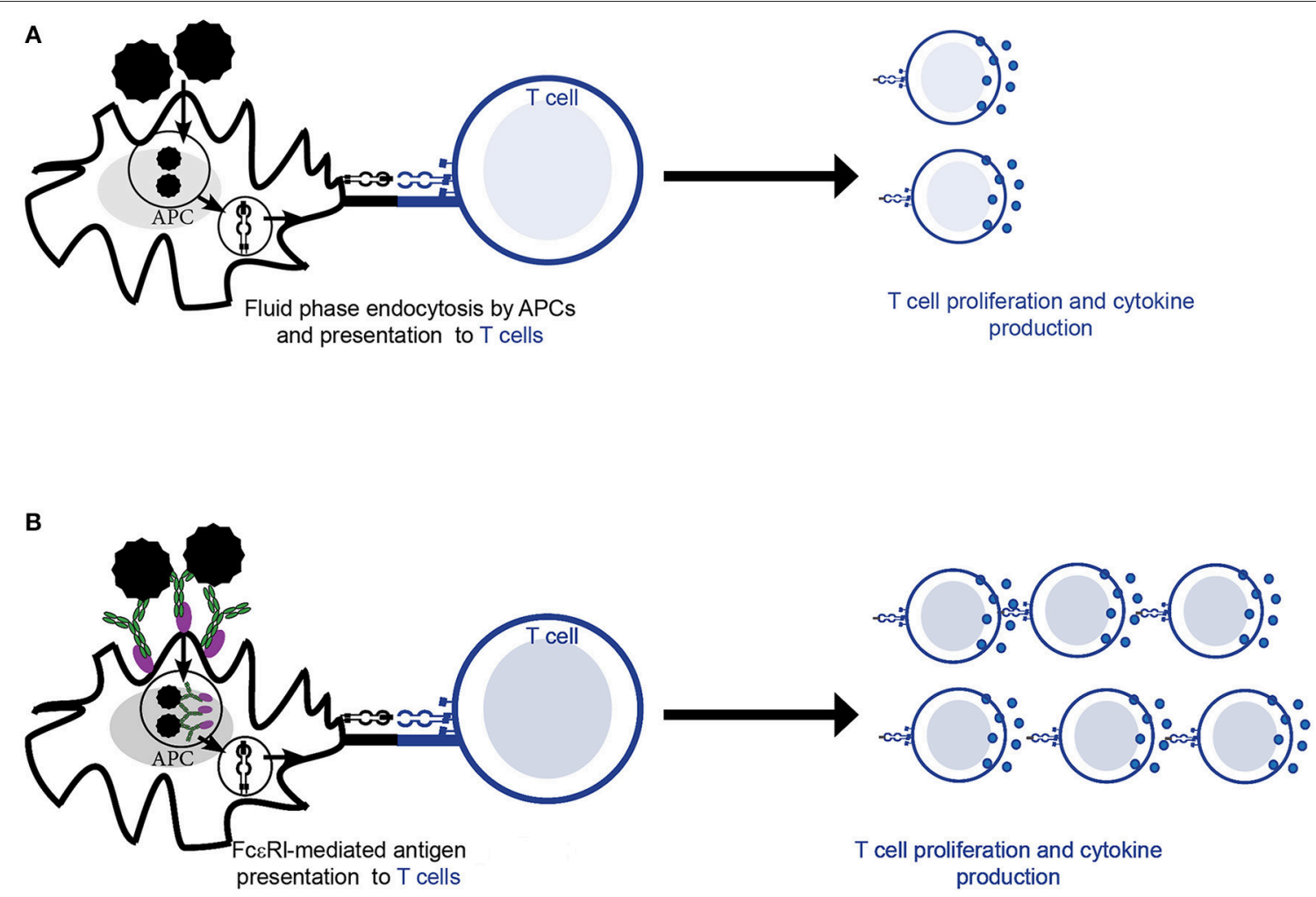

C
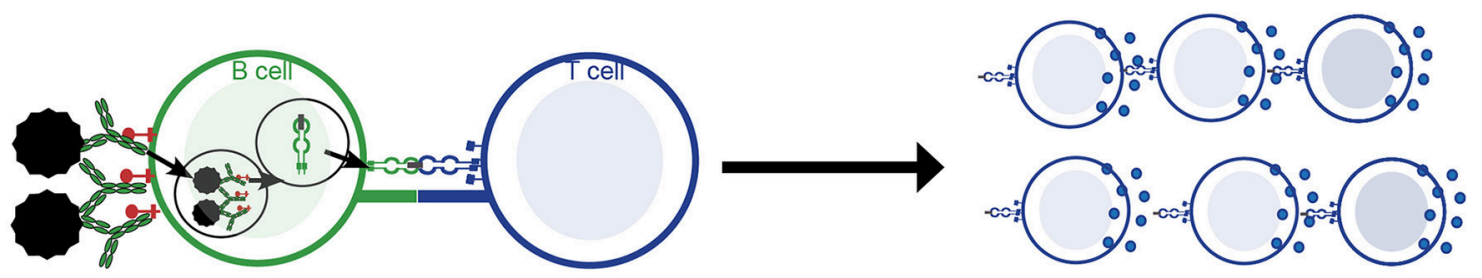

CD23-mediated antigen presentation to T cells

T cell proliferation and cytokine production

FIGURE 2 | Allergen-specific T cell activation by antigen presenting cells (APCs). (A-C) Allergen is taken up by APCs and subsequently presented to allergen-specific $\mathrm{T}$ cell cells in the context of $\mathrm{MHCll}$ and co-stimulatory molecules. This is followed by T cell activation resulting in allergen-specific proliferation and cytokine production. (A) Fluid phase endocytosis of allergen by APCs. (B) Allergen-IgE complexes are bound and internalized by the high affinity receptor for lgE (FckRI) on the surface of APCs (e.g., dendritic cells). (C) Allergen-lgE complexes are bound and internalized via the low affinity receptor for lgE (CD23) present mainly on the surface of B cells.

AIDS showed a rise in IgE levels upon seasonal allergen exposure. Thus, it is conceivable that memory $\operatorname{IgE}^{+} \mathrm{B}$ cells can also be activated solely upon antigen binding. Surpassing of the signaling threshold necessary for activation may e.g., be achieved by deposition and presentation of aggregated intact allergen or allergen-Ig complexes on the surface of follicular dendritic cells. However, it is also possible that soluble allergen itself is bound by polyclonal allergen-specific IgG and thus able to crosslink $\operatorname{IgE}^{+} \mathrm{B}$ cell receptors (BCRs) upon binding. This potential mechanism of further oligomerizing IgE-allergen-complexes by allergenspecific IgG may be called "super-crosslinking" and obviously will depend on and vary with the concentrations, affinities and specificities of allergen-specific IgG (Figure 3A). It has previously been described in the context of mast cells where only supercrosslinking of IgE-monomer complexes with allergen-specific IgG induced relevant mediator release (Figure 3B) (74). Several other mechanisms for the enhancement of allergen-induced mast cell and/or basophil activation are possible. Effects which 

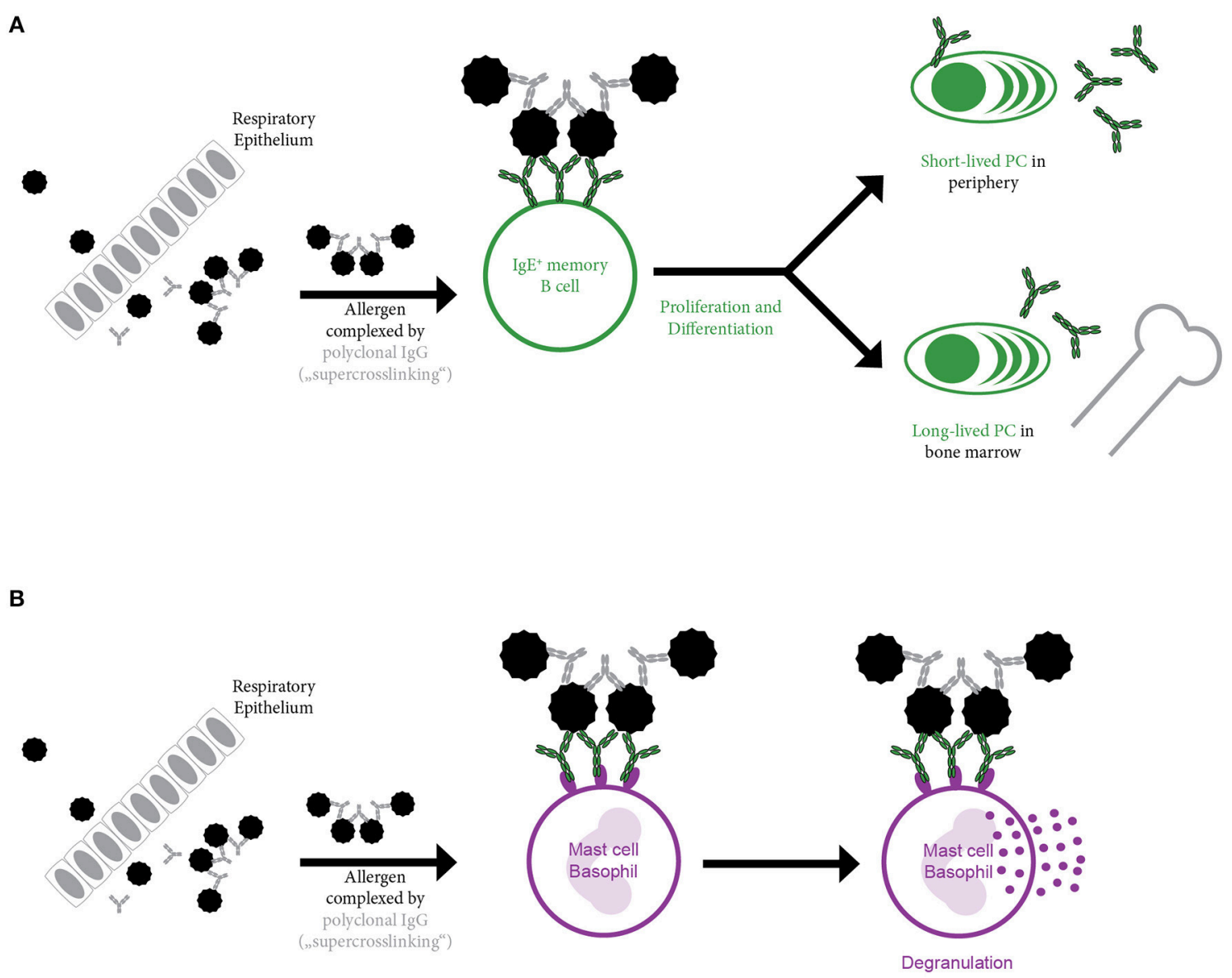

FIGURE 3 | Super-crosslinking of allergen by allergen-specific polyclonal IgG. Upon entry e.g., through the epithelium, allergen is complexed by allergen-specific polyclonal lgG. The resulting multimeric allergen complex is able to (A) induce B cell activation by crosslinking membrane bound lgE present in form of the B cell receptor (BCR) on the surface of $\operatorname{lgE}^{+}$memory $\mathrm{B}$ cells. This may result in activation of memory B cells in the absence of cognate $\mathrm{T}$ cell help and their differentiation into short-lived and long-lived plasma cells or may (B) induce basophil or mast cell activation by cross-linking of the FceRI bound IgE molecules.

are independent of allergen-specific IgG are the occurrence of repetitive IgE epitopes on allergens and the occurrence of allergens as oligomers presenting the same epitope in a repetitive manner (75-77). For the major allergen of birch, Bet $\mathrm{v} 1$, the occurrence of "catalytic" IgG antibodies has been reported which could enhance IgE binding most likely by exposing additional IgE epitopes by inducing a conformational change in the allergen (78-80). Bet v 1-specific "catalytic" IgG antibodies were even reported to enhance allergen-induced skin inflammation (81) and were considered as predictors for poor outcome of AIT (82). Alternatively, crosslinking of the $\operatorname{IgE}^{+}$BCR may also be achieved by monomeric allergen itself as crystallization studies suggested (83). Using Phl p 7 as a model allergen, it was shown that $\operatorname{IgE}$ binding occurred in the classical way via the complementary determining regions and, in addition, that IgE was able to bind simultaneously to a different epitope of the allergen via residues in the V-domain framework regions, mimicking the mechanism of "superantigens." These dual binding modes could lead to the cross-linking of $\operatorname{IgE}^{+} \mathrm{BCR}$ in the absence of allergen-specific $\operatorname{IgG}$ antibodies. There are therefore several potential mechanisms by which T cell-independent B cell activation may occur but these need to be studied in greater detail in experimental models and evaluated for their relevance for allergy in humans.

\section{EFFECTS OF AIT-INDUCED BLOCKING ANTIBODIES ON SECONDARY IMMUNE RESPONSES TO ALLERGEN}

The presence of an allergen-specific "inhibiting or immune type of substance" in post immunotherapy sera was first reported by Cooke and colleagues in 1935 (Figure 1) (84). They passively transferred serum obtained from patients before or after ragweed immunotherapy which had been mixed with the culprit allergen into the skin of non-sensitized subjects. They observed a reduced skin reaction if they applied serum from post AIT together with the allergen compared to pre-AIT allergen mixes. Subsequently, these thermostable antibodies were shown to compete for binding to the allergen with IgE, to reside in the IgG fraction and were termed "blocking" antibodies $(26,85)$. The pivotal 
role of blocking antibodies in successful AIT is emphasized by findings from a recent clinical trial where a single application of two blocking human monoclonal IgG antibodies specific for the major cat allergen Fel d 1 reduced symptoms upon nasal allergen challenge (86). The magnitude of reduction in symptoms upon a single passive immunization was similar to the one observed after years of conventional AIT.

\section{REDUCED EFFECTOR CELL ACTIVATION IN AIT-TREATED PATIENTS}

Allergen binding to IgE bound to FceRI on the surface of mast cells and basophils induces cross-linking of the receptors and hence activation of these cells (5). The interaction between allergen and IgE can be blocked by AIT-induced allergenspecific IgGs and consequently activation of effector cells is inhibited (Figure 4A). Numerous studies show a reduction in the activation of blood-derived basophils upon stimulation with allergen co-incubated with post but not pre-AIT sera $(17,87-$ 90). Allergen-specific IgGs are not only detectable in serum but also in nasal secretions of SIT treated patients $(20,21)$. Here they will also reduce mast cell activation: Upon nasal challenge with allergen, AIT treated patients show reduced histamine, tosyl L-arginine methyl ester-esterase and kinins levels in nasal fluids (91). This was associated with a beneficial effect on nasal symptoms. In this respect, an association between levels of therapy-induced Bet $\mathrm{v} 1$-specific IgG antibodies and reduced nasal sensitivity to the allergen was observed using genetically modified Bet $\mathrm{v} 1$ derivatives for treatment (21). In addition to blocking binding of allergen to IgE, IgG antibodies are also thought to modulate mast cell responses by stimulation of inhibitory circuits upon binding to Fc $\gamma$ RIIA and Fc $\gamma$ RIIB receptors on mast cells (92).

\section{Blunting of Rises in Allergen-Specific IgE Levels Induced by Seasonal Allergen Exposure in AIT Treated Patients}

Despite an initial transient rise in IgE levels upon start of subcutaneous immunotherapy (SCIT) with extracts, the allergenspecific IgE increase observed after seasonal natural pollen
A
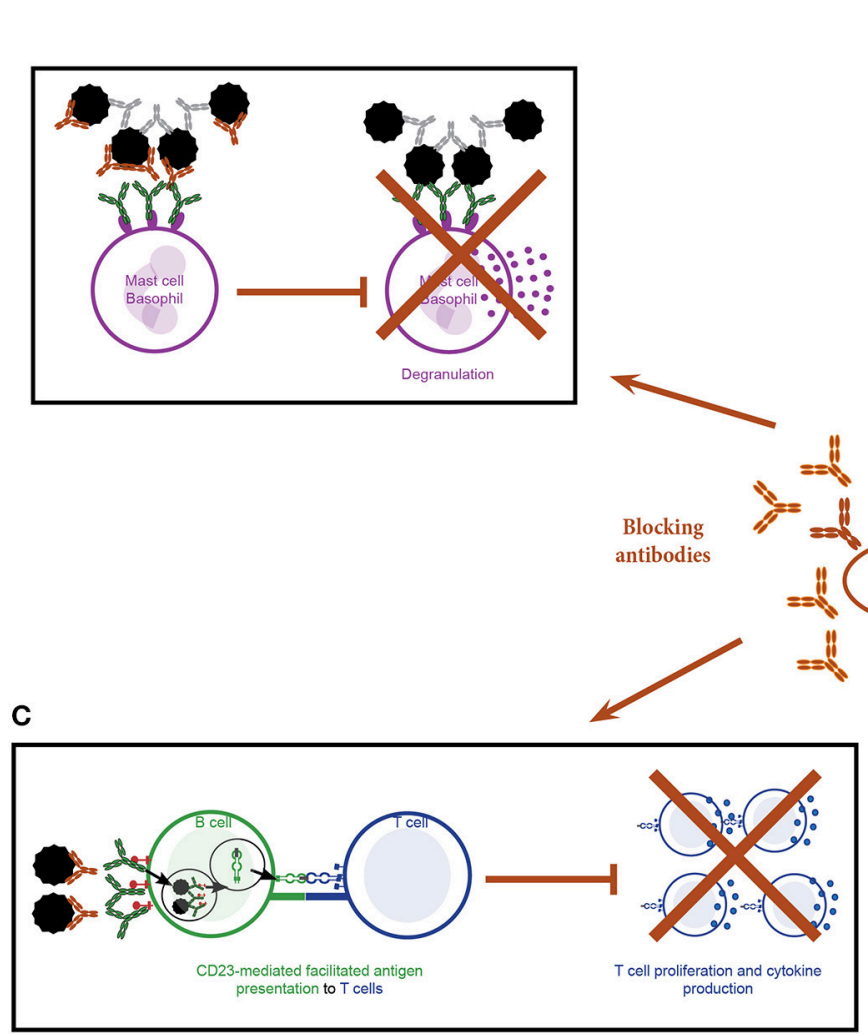

B

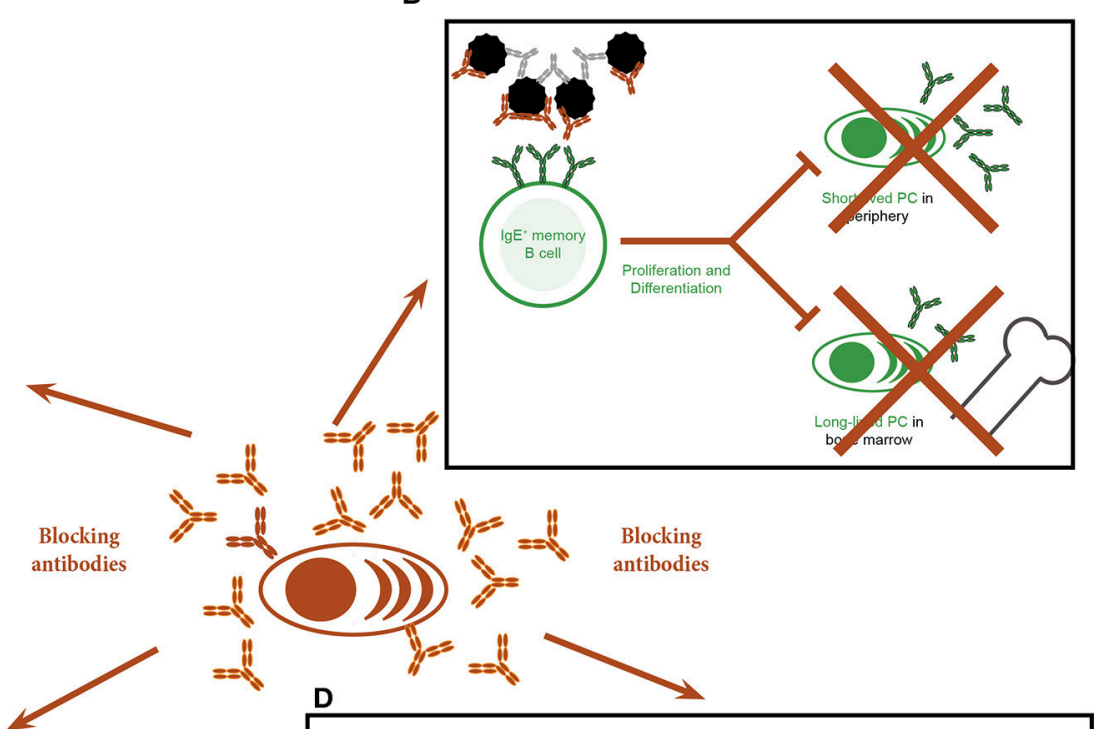

D
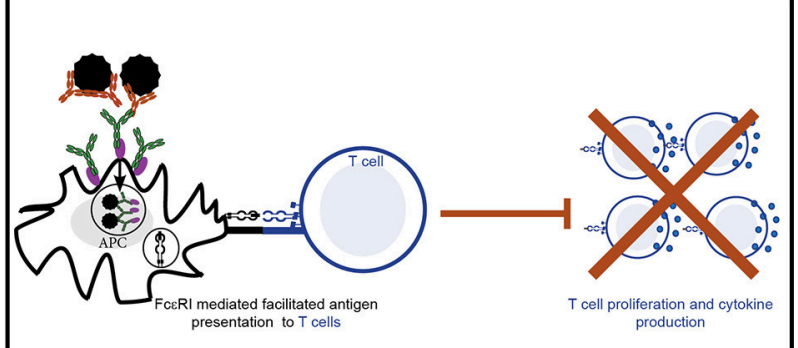

FIGURE 4 | Effects of blocking antibodies induced by specific immunotherapy. (A-D) Production of allergen-specific lgGs by plasma cells targeting the lgE-binding sites of the allergen as blocking antibodies may have the following effects: (A) Blocking of allergen-induced activation of mast cells and basophils. (B) Blocking of binding of the allergen to the $\mathrm{B}$ cell receptor on $\mathrm{Ig} \mathrm{E}^{+}$memory $\mathrm{B}$ cells and consequently inhibition of activation and differentiation of the cells. (C) Blocking of CD23-mediated, IgE-facilitated antigen presentation by B cells to T cells and hence T cell activation and differentiation. (D) Blocking of FceRI-mediated, IgE-facilitated antigen presentation by B cells to T cells and hence T cell activation and differentiation. 
exposure is blunted during SCIT (31, 93-95). To surpass the disadvantages of conventional SCIT, efforts during the last decades focused on developing alternative approaches to achieve shorter treatment regimens as well as to reduce the risk of serious adverse side effects. To reduce the number of AIT vaccinations, new adjuvants strategies such as co-engagement of toll like receptors by conjugation of pollen allergens to monophoshoryl lipid A (88) or phosphorothioate oligodeoxyribonucleotide immunostimulatory DNA sequences (96) have been investigated in clinical trials. These studies also confirmed reduced seasonal augmentation of allergen-specific IgE levels observed during conventional AIT. In this line, also hypoallergenic derivatives of birch pollen have been shown to induce protective IgG antibodies that inhibited seasonal allergen-specific IgE rises as well allergeninduced effector cell responses (97). To engineer a vaccine that raises protective IgG antibodies but at the same time reduces both IgE- and $\mathrm{T}$ cell-mediated side effects, non-allergenic peptides from the IgE binding sites of major grass pollen allergens have been fused to the hepatitis B pre $S$ protein $(98,99)$. After only three pre-seasonal vaccinations, a blunting of the seasonal allergen-specific IgE rise compared to the placebo group was achieved (100). Again, this coincided with the occurrence of allergen-specific IgG antibodies of the $\operatorname{IgG}_{1}$ and $\operatorname{IgG}_{4}$ subclass. Interestingly, this vaccine did also not induce an initial rise of $\operatorname{IgE}$ levels as observed during allergen extract-based SCIT and SLIT.

As an alternative to subcutaneous application, allergen extract can also be applied in a sublingual form (SLIT). However, direct comparison of SLIT and SCIT vs. placebo for a period of 3 years did not reveal any effect of SLIT on seasonal changes in allergen-specific IgE levels in contrast to SCIT (101).

Taken together SCIT leads to diminished rises in allergeninduced IgE levels induced by seasonal allergen exposure. This is most likely due to decreased IgE production. The latter can be explained by SCIT-induced blocking IgGs which inhibit binding of the allergen to the $\mathrm{IgE}^{+} \mathrm{BCR}$ and thus reducing the activation of memory $\operatorname{IgE}^{+} \mathrm{B}$ cells (Figure 4B) $(3,4)$.

\section{Reduced T Cell-Mediated Late Phase Responses in AIT- and Omalizumab-Treated Patients}

Successful AIT is also associated with a reduction in the $\mathrm{T}$ cellmediated late phase responses in target organs of allergy such as the skin, lung and nose $(11,14,15,102-104)$. In nasal mucosa of AIT-treated allergic patients the seasonal influx of CD3+ T cells is reduced (105) and nasal fluids bear reduced Th2 cytokine levels upon allergen challenge (106). Alongside with the decrease in IL4 expressing cells there is an increase in the ratio of IFN- $\gamma:$ IL- 5 mRNA expressing cells $(102,103,105)$. These effects coincide with the rise in blocking IgG antibodies and therefore blocking of IgE-mediated FAP is likely to account at least for part of the observed effect on $\mathrm{T}$ cells.

Blocking of IgE-facilitated antigen presentation by complexing allergen with serum IgG from patients undergoing birch pollen SIT was first demonstrated by van Neerven and co-workers (Figures 1, 4C,D) (27). Since then numerous studies confirmed that AIT induced IgGs block binding of IgE-allergencomplexes to $\mathrm{CD} 23$, a process called IgE-facilitated antigen binding (FAB) (Table 1) (12, 22, 27, 65, 106-119, 125-127). Among the IgG subclasses, FAB blocking ability is mostly attributed to allergen-specific $\operatorname{IgG}_{4}$ antibodies. $\operatorname{IgG}_{1}$ may have the same effects but this has not been studied in depth (112). Though the inhibition of FAB diminishes slowly after end of AIT treatment, inhibition of CD23-mediated allergen binding to $\mathrm{B}$ cells can be observed up to 2 years after discontinuation of immunotherapy $(12,22,106,110,117)$. Interestingly, it has been observed that this persisting effect on FAB was not necessarily associated with the levels of allergen-specific IgG but may also depend on the avidity (22). Thus, it seems that the inhibitory bioactivity rather than the absolute levels of IgGs play a role in maintaining inhibition of FAB. Despite the FAB assay being a relatively fast and easy way of determining blocking activity of antibodies it bears one main limitation: It measures blocking of binding of an indicator serum derived from a patient with high allergen-specific IgE levels to a B cell line expressing high levels of CD23. Therefore, it may be difficult to directly translate these findings into potential effects of IgG on FAP in vivo for a given patient. However, in order to investigate the effect of blocking IgG on FAP in the treated patients a modification of the assay has been developed which allows to assess the direct blocking effect of immunotherapy-induced IgG antibodies on $\mathrm{T}$ cell proliferation in vitro for each of the treated patients (87). In the study describing the modified FAP assay, allergens were pre-incubated with sera derived from patients pre or post treatment with SIT or placebo before adding them directly to PBMCs cultures derived from the autologous patient. Using this model, a significant reduction in $\mathrm{T}$ cell proliferation in patients undergoing AIT- compared to placebo-treated controls was observed and confirmed the importance of IgG blocking antibodies in inhibiting FAP. However, it must be born in mind that so far the results of such in vitro FAP assays has not been associated with clinical parameters of late phase allergic inflammation and it is has therefore not been shown that the assay can be used as a surrogate for clinical outcome of AIT. The same is true for in vitro assays measuring the blocking of allergen-induced basophil activation by AIT-induced IgG.

The hypothesis that allergen-specific IgE levels influence $\mathrm{T}$ cell responses is supported by findings from therapeutic strategies directly targeting and thus reducing serum IgE levels such as omalizumab. Omalizumab is a monoclonal anti-IgE antibody binding to the constant region 3 of $\operatorname{IgE}$ and hence inhibits binding of IgE to its receptors FceRI and $\operatorname{CD} 23(128,129)$. Treament with omalizumab reduces levels of free serum IgE by 95\% and leads to reduced exacerbations and corticosteroid use in asthmatic patients (130-132). Interestingly, it also attenuates late phase responses upon allergen challenge in lung as well as in skin of atopic subjects $(7,123)$ (Table 1). In this context it has been reported that there is a reduction in IL-13+ CD3+ lymphocytes (9) as well as in IL-13 levels (121) in the blood of omalizumab-treated patients. But the effect of omalizumab is also evident locally in target organs of allergy such as the lung: Diminished levels of CD3, CD4, CD8 lymphocytes as well as reduced staining for IgE and IL-4 were observed in the 


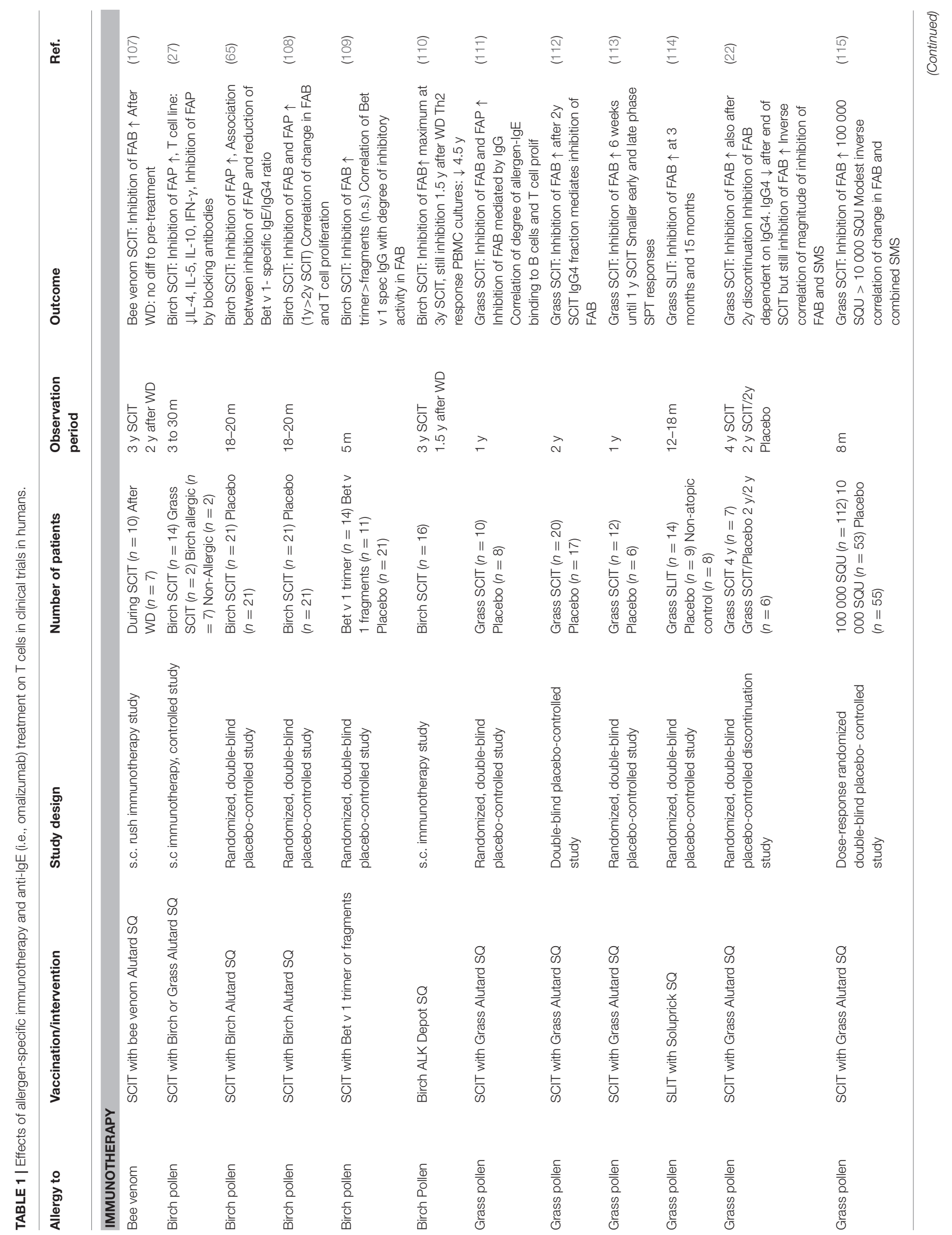




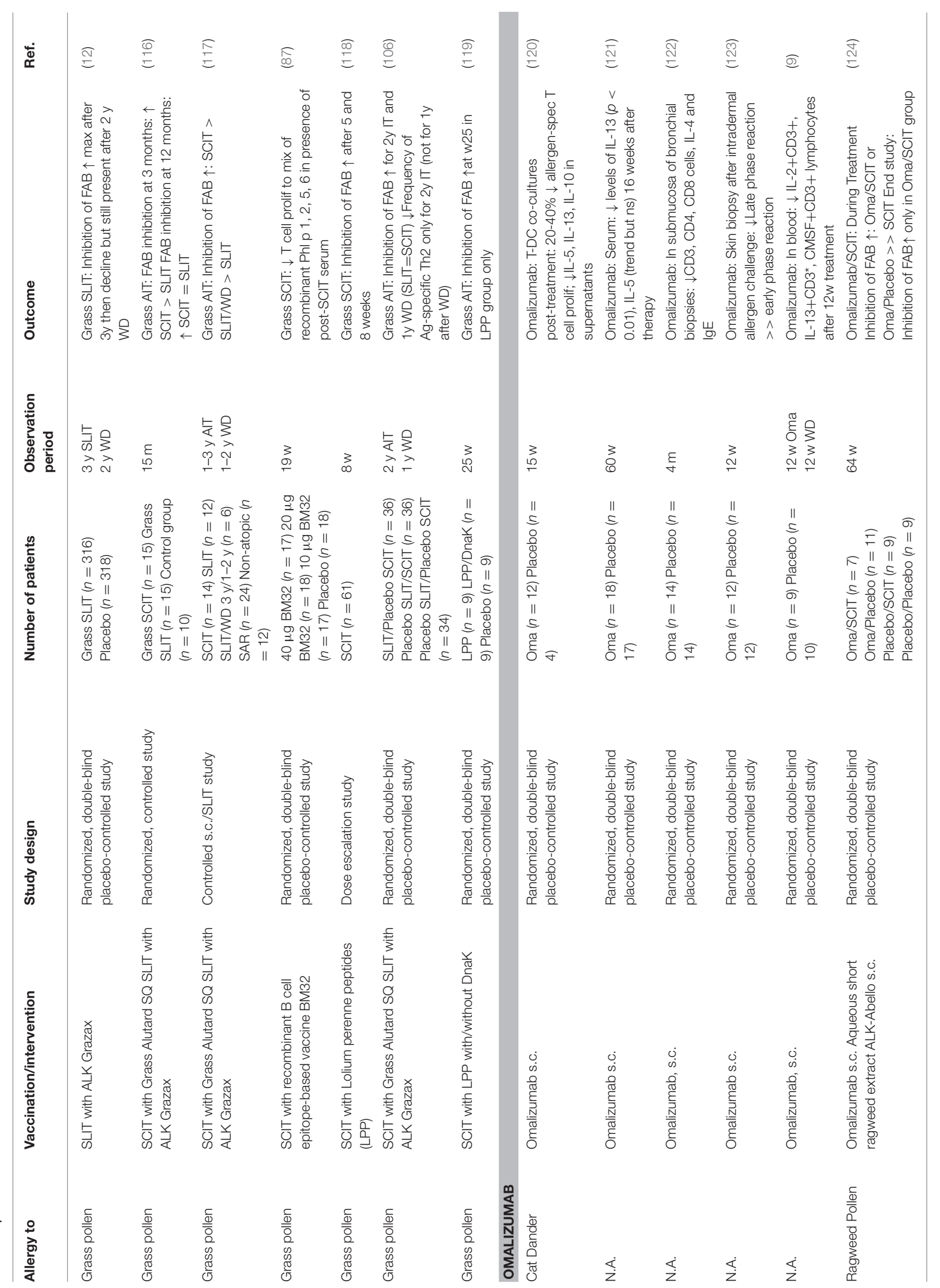


submucosa of bronchial biopsies of omalizumab-treated patients (122). All these aforementioned results indicate that the decrease in free IgE levels upon omalizumab treatment also influences IgEfacilitated allergen presentation via IgE receptors and subsequent $\mathrm{T}$ cell stimulation (Table 1). In this respect, allergen-induced proliferation in $\mathrm{DC} / \mathrm{T}$ co-cultures was reduced by $20-40 \%$ in patients undergoing treatment with omalizumab (120).

The observation that there is a cumulative effect of both AIT and omalizumab treatment on FAB especially after discontinuation of the treatment (124) supports the hypothesis that both allergen-specific IgE and IgG antibodies are important in regulating allergen-specific $\mathrm{T}$ cell responses.

In addition to producing antibodies, a subset of IL-10 producing regulatory $B$ cells, the so called $B_{R} 1$ cells, may also exert immunomodulatory effects on $\mathrm{T}$ cell proliferation in allergic responses (133). This population of $\mathrm{B}$ cells was isolated from the blood of patients undergoing bee venom immunotherapy and is characterized by high surface expression of CD25 and CD71 as well as low expression of CD73 (134). In this study $B_{R} 1$ cells were shown to both suppress antigenspecific $\mathrm{T}$ cell proliferation in an IL-10 dependent manner and to selectively upregulate $\operatorname{IgG}_{4}$ production upon differentiation into plasma cells. However, the importance of $B_{R} 1$ and other regulatory $\mathrm{B}$ cell subsets in mediating immunomodulatory effects in the context of immunotherapies targeted inhalant allergens warrants further investigation. Furthermore, the antigen-specificity of the $\mathrm{IgG}_{4}$ responses needs to be investigated.

\section{CONCLUSION}

There is no doubt, that allergen-specific T cell help is critically required for the establishment of an allergen-specific $\operatorname{IgE}$ response and the process called allergic sensitization (i.e., primary allergic immune response) which leads to the establishment of an allergic immune response. However, there is compelling evidence that once allergic sensitization has occurred in an allergic individual, the secondary allergen-specific IgE and $\mathrm{T}$

\section{REFERENCES}

1. Bønnelykke K, Sparls R, Waage J, Milner JD. Genetics of allergy and allergic sensitization: common variants, rare mutations. Curr Opin Immunol. (2015) 36:115-26. doi: 10.1016/j.coi.2015.08.002

2. Neunkirchner A, Kratzer B, Köhler C, Smole U, Mager LF, Schmetterer $\mathrm{KG}$, et al. Genetic restriction of antigen-presentation dictates allergic sensitization and disease in humanized mice. EBioMedicine (2018) 31:66-78. doi: 10.1016/j.ebiom.2018.04.001

3. Valenta R, Karaulov A, Niederberger V, Gattinger P, van Hage M, Flicker $\mathrm{S}$, et al. Molecular Aspects of Allergens and Allergy. Adv Immunol. (2018) 138:195-256. doi: 10.1016/bs.ai.2018.03.002

4. Flicker S, Valenta R. Renaissance of the blocking antibody concept in type I allergy. Int Arch Allergy Immunol. (2003) 132:13-24. doi: 10.1159/0000 73260

5. Bischoff SC. Role of mast cells in allergic and non-allergic immune responses: comparison of human and murine data. Nat Rev Immunol. (2007) 7:93-104. doi: $10.1038 /$ nri2018

6. van der Heijden FL, Joost van Neerven RJ, van Katwijk M, Bos JD, Kapsenberg ML. Serum-IgE-facilitated allergen presentation in atopic disease. J Immunol. (1993) 150(8 Pt 1):3643-50. cell response is regulated by allergen-specific $\operatorname{IgE}$ and $\operatorname{IgG}$ antibodies. It has been demonstrated that allergen-specific IgG antibodies which are for example induced during AIT and are directed against the IgE binding sites of allergens can prevent allergen-induced immediate and delayed allergic inflammation as well as specific IgE production. This can be achieved by inhibition of allergen-induced cross-linking of $\operatorname{IgE}$ bound to high affinity receptors for IgE on mast cells and basophils, by inhibition of IgE-facilitated allergen presentation to T cells and by preventing boosts of allergen-induced $\operatorname{IgE}$ production by IgE memory B cells by blocking IgG antibodies. Much less is known about the potential role of allergen-specific IgG in enhancing allergen-specific immune responses but it is possible that under certain conditions allergen-specific IgG may super-crosslink allergen-IgE immune complexes on B cells, mast cells, basophils and eventually APCs and thus contribute to boosting of secondary allergen-specific IgE production in the absence of $\mathrm{T}$ cell help, to the enhancement or blocking of allergen-induced basophil and mast cell activation and may also have as yet unknown effects on IgE-facilitated allergen presentation and $\mathrm{T}$ cell activation. The role of the latter mechanisms and their biological effects need further investigations.

\section{AUTHOR CONTRIBUTIONS}

JE-D, SV-M, BL, and RV wrote the manuscript. JE-D, RV and SV-M designed the Figures and Table. AK, YZ, MK, and VN-L critically read and revised the manuscript.

\section{FUNDING}

Supported by grants F4605, F4613 and DK1248-B13 from the Austrian Science Fund (FWF), by the Russian Academic Excellence Project 5-100 and by a Megagrant of the Government of the Russian Federation, grant No 14.W03.31.0024.

7. Fahy JV, Fleming HE, Wong HH, Liu JT, Su JQ, Reimann J, et al. The effect of an anti-IgE monoclonal antibody on the early- and late-phase responses to allergen inhalation in asthmatic subjects. Am J Respir Crit Care Med. (1997) 155:1828-34. doi: 10.1164/ajrccm.155.6.9196082

8. Eckman JA, Sterba PM, Kelly D, Alexander V, Liu MC, Bochner BS, et al. Effects of omalizumab on basophil and mast cell responses using an intranasal cat allergen challenge. J Allergy Clin Immunol. (2010) 125:889-895. doi: 10.1016/j.jaci.2009.09.12

9. Noga O, Hanf G, Brachmann I, Klucken AC, Kleine-Tebbe J, Rosseau S, et al. Effect of omalizumab treatment on peripheral eosinophil and T-lymphocyte function in patients with allergic asthma. J Allergy Clin Immunol. (2006) 117:1493-9. doi: 10.1016/j.jaci.2006.02.028

10. Takaku Y, Soma T, Nishihara F, Nakagorne K, Kobayashi T, Hagiwara K, et al. Omalizumab attenuates airway inflammation and interleukin-5 production by mononuclear cells in patients with severe allergic asthma. Int Arch Allergy Immunol. (2013) 161(Suppl. 2):107-17. doi: 10.1159/000350852

11. Durham SR, Walker SM, Varga EM, Jacobson MR, O’Brien F, Noble W, et al. Long-term clinical efficacy of grass-pollen immunotherapy. $N$ Engl J Med. (1999) 341:468-75. doi: 10.1056/NEJM199908123410702

12. Durham SR, Emminger W, Kapp A, de Monchy JG, Rak S, Scadding GK, et al. SQ-standardized sublingual grass immunotherapy: confirmation of 
disease modification 2 years after 3 years of treatment in a randomized trial. J Allergy Clin Immunol. (2012) 129:717-25 e5. doi: 10.1016/j.jaci.2011. 12.973

13. Larche $M$, Akdis CA, Valenta R. Immunological mechanisms of allergen-specific immunotherapy. Nat Rev Immunol. (2006) 6:761-71. doi: 10.1038/nri1934

14. Shamji MH, Durham SR. Mechanisms of allergen immunotherapy for inhaled allergens and predictive biomarkers. J Allergy Clin Immunol. (2017) 140:1485-98. doi: 10.1016/j.jaci.2017.10.010

15. Kappen JH, Durham SR, Veen HI, Shamji MH. Applications and mechanisms of immunotherapy in allergic rhinitis and asthma. Ther Adv Respir Dis. (2017) 11:73-86. doi: 10.1177/1753465816669662

16. Valenta $R$, Ball $T$, Focke $M$, Linhart $B$, Mothes $N$, Niederberger V, et al. Immunotherapy of allergic disease. Adv Immunol. (2004) 82:105-53. doi: 10.1016/S0065-2776(04)82003-0

17. Ball T, Sperr WR, Valent P, Lidholm J, Spitzauer S, Ebner C, et al. Induction of antibody responses to new B cell epitopes indicates vaccination character of allergen immunotherapy. Eur J Immunol. (1999) 29:2026-6. doi: 10.1002/ (SICI) 1521-4141(199906)29:06<2026::AID-IMMU2026>3.0.CO;2-2

18. Devey ME, Wilson DV, Wheeler AW. The IgG subclasses of antibodies to grass pollen allergens produced in hay fever patients during hyposensitization. Clin Allergy (1976) 6:227-36.

19. van der Giessen M, Homan WL, van Kernbeek G, Aalberse RC, Dieges PH. Subclass typing of IgG antibodies formed by grass pollen-allergic patients during immunotherapy. Int Arch Allergy Appl Immunol. (1976) 50:625-40.

20. Platts-Mills TA, von Maur RK, Ishizaka K, Norman PS, Lichtenstein LM. $\operatorname{IgA}$ and IgG anti-ragweed antibodies in nasal secretions. Quantitative measurements of antibodies and correlation with inhibition of histamine release. J Clin Invest. (1976) 57:1041-50. doi: 10.1172/JCI108346

21. Reisinger J, Horak F, Pauli G, van Hage M, Cromwell O, Konig F, et al. Allergen-specific nasal IgG antibodies induced by vaccination with genetically modified allergens are associated with reduced nasal allergen sensitivity. J Allergy Clin Immunol. (2005) 116:347-54. doi: 10.1016/j.jaci.2005.04.003

22. James LK, Shamji MH, Walker SM, Wilson DR, Wachholz PA, Francis JN, et al. Long-term tolerance after allergen immunotherapy is accompanied by selective persistence of blocking antibodies. J Allergy Clin Immunol. (2011) 127:509-16 e1-5. doi: 10.1016/j.jaci.2010.12.1080

23. van de Veen W, Akdis M. Role of IgG4 in IgE-mediated allergic responses. J Allergy Clin Immunol. (2016) 138:1434-5. doi: 10.1016/j.jaci.2016. 07.022

24. van der Zee JS, van Swieten P, Aalberse RC. Serologic aspects of IgG4 antibodies. II. IgG4 antibodies form small, nonprecipitating immune complexes due to functional monovalency. J Immunol. (1986) 137:3566-71.

25. van der Neut Kolfschoten M, Schuurman J, Losen M, Bleeker WK, MartinezMartinez P, Vermeulen E, et al. Anti-inflammatory activity of human IgG4 antibodies by dynamic Fab arm exchange. Science (2007) 317:1554-7. doi: $10.1126 /$ science. 1144603

26. Loveless MH. Immunological studies of pollenosis. I. The presence of two antibodies related to the same pollen antigen in the serum of treated hay fever patients. J Immunol. (1940) 38:25-50.

27. van Neerven RJ, Wikborg T, Lund G, Jacobsen B, Brinch-Nielsen A, Arnved $\mathrm{J}$, et al. Blocking antibodies induced by specific allergy vaccination prevent the activation of $\mathrm{CD} 4+\mathrm{T}$ cells by inhibiting serum-IgE-facilitated allergen presentation. J Immunol. (1999) 163:2944-52.

28. Dunbar WP. Zur Ursache und spezifischen Heilung des Heufiebers. Deutsche Medizinische Wochenschrift (1903) 9:24-8.

29. Ishizaka K, Ishizaka T, Hornbrook MM. Physicochemicalproperties of reaginic antibody: $\mathrm{V}$ Correlation of reaginic activity with $\gamma \mathrm{E}$-globulin antibody. J Immunol, (1966) 97:840-53.

30. Wide L, Bennich H, Johansson SG. Diagnosis of allergy by an in-vitro test for allergen antibodies. Lancet (1967) 2:1105-7.

31. Levy DA, Osler AG. Studies on the mechanisms of hypersensitivity phenomena. XVI. In vitro assays of reaginic activity in human sera: effect of therapeutic immunization on seasonal titer changes. J Immunol. (1967) 99:1068-77.

32. Henderson LL, Larson JB, Gleich GJ. Maximal rise in IgE antibody following ragweed pollination season. J Allergy Clin Immunol. (1975) 55:10-5.
33. Niederberger V, Ring J, Rakoski J, Jager S, Spitzauer S, Valent P, et al. Antigens drive memory IgE responses in human allergy via the nasal mucosa. Int Arch Allergy Immunol. (2007) 142:133-44. doi: 10.1159/000096439

34. Oettgen HC. Fifty years later: emerging functions of IgE antibodies in host defense, immune regularion, and allergic diseases. J Allergy Clin Immunol. (2016) 137:1631-45. doi: 10.1016/j.jaci.2016.04.009

35. Legendre C, Caillat-Zucman S, Samuel D, Morelon S, Bismuth H, Bach JF, et al. Transfer of symptomatic peanut allergy of the recipient of a combined liver-and-kidney transplant. N Engl J Med. (1997) 337:822-4. doi: 10.1056/NEJM199709183371204

36. MacGlashan DW Jr, Bochner BS, Adelman DC, Jardieu PM, Togias A, McKenzie-White J, et al. Down-regulation of Fc(epsilon)RI expression on human basophils during in vivo treatment of atopic patients with anti-IgE antibody. J Immunol. (1997) 158:1438-45.

37. Waldmann TA, Iio A, Ogawa M, McIntyre OR, Strober W. The metabolism of IgE. Studies in normal individuals and in a patient with IgE myeloma. $J$ Immunol. (1976) 117:1139-44.

38. Meno-Tetang GM, Lowe PJ. On the prediction of the human response: a recycled mechanistic pharmacokinetic/pharmacodynamic approach. Basic Clin Pharmacol Toxicol. (2005) 96:182-92. doi: 10.1111/j.1742-7843.2005.pto960307.x

39. Dullaers M, De Bruyne R, Ramadani F, Gould HJ, Gevaert P, Lambrecht BN. The who, where, and when of IgE in allergic airway disease. J Allergy Clin Immunol. (2012) 129:635-45. doi: 10.1016/j.jaci.2011.10.029

40. Horst A, Hunzelmann N, Arce S, Herber M, Manz RA, Radbruch A, et al. Detection and characterization of plasma cells in peripheral blood: correlation of IgE+ plasma cell frequency with IgE serum titre. Clin Exp Immunol. (2002) 130:370-8. doi: 10.1046/j.1365-2249.2002.02025.x

41. Berkowska MA, Heeringa JJ, Hajdarbegovic E, van der Burg M, Thio HB, van Hagen PM, et al. Human $\operatorname{IgE}(+)$ B cells are derived from T cell-dependent and T cell-independent pathways. J Allergy Clin Immunol. (2014) 134:688-97 e6. doi: 10.1016/j.jaci.2014.03.036

42. Wong KJ, Timbrell V, Xi Y, Upham JW, Collins AM, Davies JM. IgE+ B cells are scarce, but allergen-specific $B$ cells with a memory phenotype circulate in patients with allergic rhinitis. Allergy (2015) 70:420-8. doi: 10.1111/all.12563

43. Heeringa JJ, Rijvers L, Arends NJ, Driessen GJ, Pasmans SG, van Dongen JJM, et al. IgE-expressing memory B cells and plasmablasts are increased in blood of children with asthma, food allergy, and atopic dermatitis. Allergy (2018) 73:1331-6. doi: 10.1111/all.13421

44. Selb R, Eckl-Dorna J, Neunkirchner A, Schmetterer K, Marth K, Gamper J, et al. CD23 surface density on B cells is associated with IgE levels and determines IgE-facilitated allergen uptake, as well as activation of allergen-specific T cells. J Allergy Clin Immunol. (2017) 139:290-9 e4. doi: $10.1016 /$ j.jaci.2016.03.042

45. Eckl-Dorna J, Pree I, Reisinger J, Marth K, Chen KW, Vrtala S, et al. The majority of allergen-specific IgE in the blood of allergic patients does not originate from blood-derived B cells or plasma cells. Clin Exp Allergy (2012) 42:1347-55. doi: 10.1111/j.1365-2222.2012.04030.x

46. Eckl-Dorna J, Niederberger V. What is the source of serum allergen-specific IgE? Curr Allergy Asthma Rep. (2013) 13:281-7. doi: $10.1007 / \mathrm{s} 11882-013-0348-\mathrm{x}$

47. Smurthwaite L, Walker SN, Wilson DR, Birch DS, Merrett TG, Durham SR, et al. Persistent IgE synthesis in the nasal mucosa of hay fever patients. Eur J Immunol. (2001) 31:3422-31. doi: 10.1002/1521-4141(200112)31:12<3422::AID-IMMU3422>3.0.CO;2-T

48. Durham SR, Smurthwaite L, Gould HJ. Local IgE production. Am J Rhinol Allergy(2000) 14:305-7.

49. Walker SA, Riches PG, Wild G, Ward AM, Shaw PJ, Desai S, et al. Total and allergen-specific $\operatorname{IgE}$ in relation to allergic response pattern following bone marrow transplantation. Clin Exp Immunol. (1986) 66:633-9.

50. Naclerio RM, Adkinson NF, Jr, Moylan B, Baroody FM, Proud D, KageySobotka A, et al. Nasal provocation with allergen induces a secondary serum IgE antibody response. J Allergy Clin Immunol. (1997) 100:505-10.

51. Egger C, Lupinek C, Ristl R, Lemell P, Horak F, Zieglmayer $\mathrm{P}$, et al. Effects of nasal corticosteroids on boosts of systemic allergen-specific $\operatorname{IgE}$ production induced by nasal allergen exposure. PLoS ONE (2015) 10:e0114991. doi: 10.1371/journal.pone. 0114991 
52. Eckl-Dorna J, Froschl R, Lupinek C, Kiss R, Gattinger P, Marth K, et al. Intranasal administration of allergen increases specific IgE whereas intranasal omalizumab does not increase serum IgE levels-A pilot study. Allergy (2018) 73:1009-12. doi: 10.1111/all.13343

53. Platts-Mills TA. Local production of IgG, IgA and IgE antibodies in grass pollen hay fever. J Immunol. (1979) 122:2218-25.

54. Curin M, Swoboda I, Wollmann E, Lupinek C, Spitzauer S, van Hage M, et al. Microarrayed dog, cat, and horse allergens show weak correlation between allergen-specific IgE and IgG responses. J Allergy Clin Immunol. (2014) 133:918-21 e6. doi: 10.1016/j.jaci.2013.10.058

55. Niederberger V, Niggemann B, Kraft D, Spitzauer S, Valenta R. Evolution of IgM, IgE and IgG(1-4)antibody responses in early childhood monitored with recombinant allergen components: implications for class switch mechanisms. Eur J Immunol. (2002) 32:576-84. doi: 10.1002/1521-4141(200202)32:2<576::AID-IMMU576>3.0.CO;2-U

56. Huang X, Tsilochristou O, Perna S, Hofmaier S, Cappella A, Bauer CP, et al. Evolution of the $\operatorname{IgE}$ and $\operatorname{IgG}$ repertoire to a comprehensive array of allergen molecules in the first decade of life. Allergy (2018) 73:421-30. doi: 10.1111/all.13269

57. van der Heijden FL, van Neerven RJ, Kapsenberg ML. Relationship between facilitated allergen presentation and the presence of allergen-specific $\operatorname{IgE}$ in serum of atopic patients. Clin Exp Immunol. (1995) 99:289-93.

58. Mudde GC, Van Reijsen FC, Boland GJ, de Gast GC, Bruijnzeel PL, Bruijnzeel-Koomen CA. Allergen presentation by epidermal Langerhans' cells from patients with atopic dermatitis is mediated by IgE. Immunology (1990) 69:335-41.

59. Maurer D, Ebner C, Reininger B, Fiebiger E, Kraft D, Kinet JP, et al. The high affinity IgE receptor (Fc epsilon RI) mediates IgE-dependent allergen presentation. J Immunol. (1995) 154:6285-90.

60. Mudde GC, Bheekha R, Bruijnzeel-Koomen CA. IgE-mediated antigen presentation. Allergy (1995) 50:193-9.

61. Pirron U, Schlunck T, Prinz JC, Rieber EP. IgE-dependent antigen focusing by human B lymphocytes is mediated by the low-affinity receptor for IgE. Eur J Immunol. (1990) 20:1547-51. doi: 10.1002/eji.18302 00721

62. Santamaria LF, Bheekha R, van Reijsen FC, Perez Soler MT, Suter M, Bruijnzeel-Koomen CA, et al. Antigen focusing by specific monomeric immunoglobulin E bound to CD23 on Epstein-Barr virus-transformed B cells. Hum Immunol. (1993) 37:23-30.

63. Reginald K, Eckl-Dorna J, Zafred D, Focke-Tejkl M, Lupinek C, Niederberger $\mathrm{V}$, et al. Different modes of IgE binding to CD23 revealed with major birch allergen, Bet v 1-specific monoclonal IgE. Immunol Cell Biol. (2013) 91:167-72. doi: 10.1038/icb.2012.70

64. Holm J, Willumsen N, Wurtzen PA, Christensen LH, Lund K. Facilitated antigen presentation and its inhibition by blocking IgG antibodies depends on IgE repertoire complexity. J Allergy Clin Immunol. (2011) 127:1029-37. doi: 10.1016/j.jaci.2011.01.062

65. van Neerven RJ, Arvidsson M, Ipsen H, Sparholt SH, Rak S, Wurtzen PA. A double-blind, placebo-controlled birch allergy vaccination study: inhibition of CD23-mediated serum-immunoglobulin Efacilitated allergen presentation. Clin Exp Allergy (2004) 34:420-8. doi: 10.1111/j.1365-2222.2004.01899.x

66. Poole JA, Meng J, Reff M, Spellman MC, Rosenwasser LJ. AntiCD23 monoclonal antibody, lumiliximab, inhibited allergen-induced responses in antigen-presenting cells and $\mathrm{T}$ cells from atopic subjects. J Allergy Clin Immunol. (2005) 116:780-8. doi: 10.1016/j.jaci.2005. 07.007

67. Nakamura T, Kloetzer WS, Brams P, Hariharan K, Chamat S, Cao X, et al. In vitro IgE inhibition in $\mathrm{B}$ cells by anti-CD23 monoclonal antibodies is functionally dependent on the immunoglobulin $\mathrm{Fc}$ domain. Int $J$ Immunopharmacol. (2000) 22:131-41. doi: 10.1016/S0192-0561(99)00068-5

68. Shamji MH, Kappen JH, Akdis M, Jensen-Jarolim E, Knol EF, KleineTebbe J, et al. Biomarkers for monitoring clinical efficacy of allergen immunotherapy for allergic rhinoconjunctivitis and allergic asthma: an EAACI Position Paper. Allergy (2017) 72:1156-73. doi: 10.1111/all. 13138

69. Narayanan M, Freidl R, Focke-Tejkl M, Baranyi U, Wekerle T, Valenta $\mathrm{R}$, et al. A B Cell epitope peptide derived from the major grass pollen allergen $\mathrm{Phl} \mathrm{p} 1$ boosts allergen-specific secondary antibody responses without allergen-specific T cell help. J Immunol. (2017) 198:1685-95. doi: 10.4049/jimmunol.1501741

70. Linhart B, Bigenzahn S, Hartl A, Lupinek C, Thalhamer J, Valenta R, et al. Costimulation blockade inhibits allergic sensitization but does not affect established allergy in a murine model of grass pollen allergy. J Immunol. (2007) 178:3924-31. doi: 10.4049/jimmunol.178.6.3924

71. Egger C, Horak F, Vrtala S, Valenta R, Niederberger V. Nasal application of rBet v 1 or non-IgE-reactive T-cell epitope-containing rBet v 1 fragments has different effects on systemic allergen-specific antibody responses. J Allergy Clin Immunol. (2010) 126:1312-5 e4. doi: 10.1016/j.jaci.2010.06.008

72. Lucae S, Schmid-Grendelmeier P, Wuthrich B, Kraft D, Valenta R, Linhart B. $\operatorname{IgE}$ responses to exogenous and endogenous allergens in atopic dermatitis patients under long-term systemic cyclosporine A treatment. Allergy (2016) 71:115-8. doi: 10.1111/all.12711

73. Marth K, Wollmann E, Gallerano D, Ndlovu P, Makupe I, Valenta $\mathrm{R}$, et al. Persistence of IgE-associated allergy and allergen-specific IgE despite CD4+ T cell loss in AIDS. PLoS ONE (2014) 9:e97893. doi: 10.1371/journal.pone.0097893

74. Sellge G, Laffer S, Mierke C, Vrtala S, Hoffmann MW, Klempnauer J, et al. Development of an in vitro system for the study of allergens and allergenspecific immunoglobulin E and immunoglobulin G: Fcepsilon receptor I supercross-linking is a possible new mechanism of immunoglobulin Gdependent enhancement of type I allergic reactions. Clin Exp Allergy (2005) 35:774-81. doi: 10.1111/j.1365-2222.2005.02248.x

75. Baar A, Pahr S, Constantin C, Giavi S, Papadopoulos NG, Pelkonen AS, et al. The high molecular weight glutenin subunit Bx7 allergen from wheat contains repetitive IgE epitopes. Allergy (2014) 69:1316-23. doi: 10.1111/all.12464

76. Göbl C, Focke-Tejkl M, Najafi N, Schrank E, Madl T, Kosol S, et al. Flexiblle IgE epitope-containing domains of Phl p 5 caise high allergenic activity. $J$ Allergy Clin Immunol. (2017) 140:1187-91. doi: 10.1016/j.jaci.2017.05.005

77. Scholl I, Kalkura N, Shedziankova Y, Bergmann A, Verdino P, Knittelfelder R, et al. Dimerization of the major birch pollen allergen Bet $\mathrm{v} 1$ is important for its in vivo IgE-cross-linking potential in mice. J Immunol. (2005) 175:664550. doi: 10.4049/jimmunol.175.10.6645

78. Visco V, Dolecek C, Denepoux S, Le Mao J, Guret C, Rousset F, et al. Human IgG monoclonal antibodies that modulate the binding of specific IgE to birch pollen Bet v 1. J Immunol. (1996) 157:956-62.

79. Laffer S, Vangelista L, Steinberger P, Kraft D, Pastore A, Valenta R. Bip 1, a monoclonal antibody with specificity for the major birch pollen allergen Bet v 1, modulates IgE binding to the allergen. Int Arch Allergy Immunol. (1997) 113:260-1.

80. Lebecque S, Dolecek C, Laffer S, Visco V, Denépoux S, Pin JJ, et al. Immunologic characterization of monoclonal antibodies that modulate human IgE binding to the major birch pollen allergen Bet v 1. J Allergy Clin Immunol. (1997) 99:374-84.

81. Denépoux S, Eibensteiner PB, Steinberger P, Vrtale S, Visco V, Weyer A, et al. Molecular characterization of human IgG monoclonal antibodies specific for the major birch pollen allergen Bet v 1. Anti-allergen IgG can enhance the anaphylactic reaction. FEBS Lett. (2000) 465:39-46. doi: 10.1016/S0014-5793(99)01703-2

82. Selb R, Eckl-Dorna J, Vrtala S, Valenta R, Niederberger V. An assay that may predict the development of IgG enhancing allergen-specific IgE binding during birch immunotherapy. Allergy (2013) 68:1199-202. doi: 10.1111/all.12204

83. Mitropoulou AN, Bowen H, Dodev TS, Davies AM, Bax HJ, Beavil RL, et al. Structure of a patient-derived antibody in complex with allergen reveals simultaneous conventional and superantigen-like recognition. Proc Natl Acad Sci USA. (2018) 115:E8707-16. doi: 10.1073/pnas.1806840115

84. Cooke RA, Barnard JH, Hebald S, Stull A. Serological evidence of immunity with coexisting sensitization in a type of human allergy (Hay Fever). J Exp Med. (1935) 62:733-50.

85. Lichtenstein LM, Holtzman NA, Burnett LS. A quantitative in vitro study of the chromatographic distribution and immunoglobulin characteristics of human blocking antibody. J Immunol. (1968) 101:317-24.

86. Orengo JM, Radin AR, Kamat V, Badithe A, Ben LH, Bennett BL, et al. Treating cat allergy with monoclonal IgG antibodies that bind 
allergen and prevent IgE engagement. Nat Commun. (2018) 9:1421. doi: 10.1038/s41467-018-03636-8

87. Zieglmayer P, Focke-Tejkl M, Schmutz R, Lemell P, Zieglmayer R, Weber $M$, et al. Mechanisms, safety and efficacy of a B cell epitope-based vaccine for immunotherapy of grass pollen allergy. EBioMedicine (2016) 11:43-57. doi: 10.1016/j.ebiom.2016.08.022

88. Mothes N, Heinzkill M, Drachenberg KJ, Sperr WR, Krauth MT, Majlesi $\mathrm{Y}$, et al. Allergen-specific immunotherapy with a monophosphoryl lipid A-adjuvanted vaccine: reduced seasonally boosted immunoglobulin E production and inhibition of basophil histamine release by therapy-induced blocking antibodies. Clin Exp Allergy (2003) 33:1198-208.

89. Clinton PM, Kemeny DM, Youlten LJ, Lessof MH. Histamine release from peripheral blood leukocytes with purified bee venom allergens: effect of hyperimmune beekeeper plasma. Int Arch Allergy Appl Immunol. (1989) 89:43-8.

90. Hoffmann HJ. News in Cellular Allergology: a review of the human mast cell and basophil granulocyte literature from January 2013 to May 2015. Int Arch Allergy Immunol. (2015) 168:253-62. doi: 10.1159/000443960

91. Furin MJ, Norman PS, Creticos PS, Proud D, Kagey-Sobotka A, Lichtenstein LM, et al. Immunotherapy decreases antigen-induced eosinophil cell migration into the nasal cavity. J Allergy Clin Immunol. (1991) 88:27-32.

92. Cady CT, Powell MS, Harbeck RJ, Giclas PC, Murphy JR, Katial RK, et al. IgG antibodies produced during subcutaneous allergen immunotherapy mediate inhibition of basophil activation via a mechanism involving both FcgammaRIIA and FcgammaRIIB. Immunol Lett. (2010) 130:57-65. doi: 10.1016/j.imlet.2009.12.001

93. Gleich GJ, Zimmermann EM, Henderson LL, Yunginger JW. Effect of immunotherapy on immunoglobulin $\mathrm{E}$ and immunoglobulin $\mathrm{G}$ antibodies to ragweed antigens: a six-year prospective study. J Allergy Clin Immunol. (1982) 70:261-71.

94. Lichtenstein LM, Ishizaka K, Norman PS, Sobotka AK, Hill BM. IgE antibody measurements in ragweed hay fever. Relationship to clinical severity and the results of immunotherapy. J Clin Invest. (1973) 52:472-82. doi: 10.1172/JCI107204

95. Peng ZK, Naclerio RM, Norman PS, Adkinson NF, Jr. Quantitative IgE- and IgG-subclass responses during and after long-term ragweed immunotherapy. J Allergy Clin Immunol. (1992) 89:519-29.

96. Creticos PS, Schroeder JT, Hamilton RG, Balcer-Whaley SL, Khattignavong AP, Lindblad R, et al. Immunotherapy with a ragweed-toll-like receptor 9 agonist vaccine for allergic rhinitis. $N$ Engl J Med. (2006) 355:1445-55. doi: 10.1056/NEJMoa052916

97. Niederberger V, Horak F, Vrtala S, Spitzauer S, Krauth MT, Valent P, et al. Vaccination with genetically engineered allergens prevents progression of allergic disease. Proc Natl Acad Sci USA. (2004) 101(Suppl. 2):14677-82. doi: $10.1073 /$ pnas. 0404735101

98. Focke-Tejkl M, Weber M, Niespodziana K, Neubauer A, Huber H, Henning $\mathrm{R}$, et al. Development and characterization of a recombinant, hypoallergenic, peptide-based vaccine for grass pollen allergy. J Allergy Clin Immunol. (2015) 135:1207-7 e1-11. doi: 10.1016/j.jaci.2014.09.012

99. Niederberger V, Marth K, Eckl-Dorna J, Focke-Tejkl M, Weber M, Hemmer $\mathrm{W}$, et al. Skin test evaluation of a novel peptide carrier-based vaccine, BM32, in grass pollen-allergic patients. J Allergy Clin Immunol. (2015) 136:1101-3 e8. doi: 10.1016/j.jaci.2015.03.034

100. Niederberger V, Neubauer A, Gevaert P, Zidarn M, Worm M, Aberer W, et al. Safety and efficacy of immunotherapy with the recombinant B-cell epitope-based grass pollen vaccine BM32. J Allergy Clin Immunol. (2018) 142:497-509 e9. doi: 10.1016/j.jaci.2017.09.052

101. Scadding GW, Calderon MA, Shamji MH, Eifan AO, Penagos M, Dumitru F, et al. Effect of 2 years of treatment with sublingual grass pollen immunotherapy on nasal response to allergen challenge at 3 years among patients with moderate to severe seasonal allergic rhinitis: the GRASS randomized clinical trial. JAMA (2017) 317:615-25. doi: 10.1001/jama.2016.21040

102. Tulic MK, Fiset PO, Christodoulopoulos P, Vaillancourt P, Desrosiers $\mathrm{M}$, Lavigne F, et al. Amb a 1-immunostimulatory oligodeoxynucleotide conjugate immunotherapy decreases the nasal inflammatory response. $J$ Allergy Clin Immunol. (2004) 113:235-41. doi: 10.1016/j.jaci.2003.11.001
103. Scadding GW, Eifan AO, Lao-Araya M, Penagos M, Poon SY, Steveling E, et al. Effect of grass pollen immunotherapy on clinical and local immune response to nasal allergen challenge. Allergy (2015) 70:689-96. doi: $10.1111 /$ all. 12608

104. Iliopoulos O, Proud D, Adkinson NF, Jr, Creticos PS, Norman PS, KageySobotka A, et al. Effects of immunotherapy on the early, late, and rechallenge nasal reaction to provocation with allergen: changes in inflammatory mediators and cells. J Allergy Clin Immunol. (1991) 87:855-66.

105. Wachholz PA, Nouri-Aria KT, Wilson DR, Walker SM, Verhoef A, Till SJ, et al. Grass pollen immunotherapy for hayfever is associated with increases in local nasal but not peripheral Th1:Th2 cytokine ratios. Immunology (2002) 105:56-62. doi: 10.1046/j.1365-2567.2002.01338.x

106. Renand A, Shamji MH, Harris KM, Qin T, Wambre E, Scadding GW, et al. Synchronous immune alterations mirror clinical response during allergen immunotherapy. J Allergy Clin Immunol. (2018) 141:1750-60 e1. doi: 10.1016/j.jaci.2017.09.041

107. Varga EM, Francis JN, Zach MS, Klunker S, Aberer W, Durham SR. Time course of serum inhibitory activity for facilitated allergen-IgE binding during bee venom immunotherapy in children. Clin Exp Allergy (2009) 39:1353-7. doi: 10.1111/j.1365-2222.2009.03303.x

108. Wurtzen PA, Lund G, Lund K, Arvidsson M, Rak S, Ipsen $H$. A double-blind placebo-controlled birch allergy vaccination study II: correlation between inhibition of $\operatorname{IgE}$ binding, histamine release and facilitated allergen presentation. Clin Exp Allergy (2008) 38:1290-301. doi: 10.1111/j.1365-2222.2008.03020.x

109. Pree I, MH, Kimber I, Valenta R, Durham SR, Niederberger V. Inhibition of CD23-dependent facilitated allergen binding to $\mathrm{B}$ cells following vaccination with genetically modified hypoallergenic Bet v 1 molecules. Clin Exp Allergy (2010) 40:1346-52. doi: 10.1111/j.1365-2222.2010.03548.x

110. Mobs C, Ipsen H, Mayer L, Slotosch C, Petersen A, Wuertzen PA, et al. Birch pollen immunotherapy results in long-term loss of Bet v 1-specific TH2 responses, transient TR1 activation, and synthesis of IgE-blocking antibodies. J Allergy Clin Immunol. (2012) 130:1108-116e6. doi: 10.1016/j.jaci.2012.07.056

111. Wachholz PA, Soni NK, Till SJ, Durham SR. Inhibition of allergen-IgE binding to B cells by IgG antibodies after grass pollen immunotherapy. $J$ Allergy Clin Immunol. (2003) 112:915-22. doi: 10.1016/S0091

112. Nouri-Aria KT, Wachholz PA, Francis JN, Jacobson MR, Walker SM, Wilcock LK, et al. Grass pollen immunotherapy induces mucosal and peripheral IL-10 responses and blocking IgG activity. J Immunol. (2004) 172:3252-9. doi: 10.4049/jimmunol.172.5.3252

113. Francis JN, James LK, Paraskevopoulos G, Wong C, Calderon MA, Durham SR, et al. Grass pollen immunotherapy: IL-10 induction and suppression of late responses precedes IgG4 inhibitory antibody activity. J Allergy Clin Immunol. (2008) 121:1120-5 e2. doi: 10.1016/j.jaci.2008.01.072

114. Scadding GW, Shamji MH, Jacobson MR, Lee DI, Wilson D, Lima MT, et al. Sublingual grass pollen immunotherapy is associated with increases in sublingual Foxp3-expressing cells and elevated allergen-specific immunoglobulin G4, immunoglobulin A and serum inhibitory activity for immunoglobulin E-facilitated allergen binding to B cells. Clin Exp Allergy (2010) 40:598-606. doi: 10.1111/j.1365-2222.2010.03462.x

115. Shamji MH, Ljorring C, Francis JN, Calderon MA, Larche M, Kimber I, et al. Functional rather than immunoreactive levels of IgG4 correlate closely with clinical response to grass pollen immunotherapy. Allergy (2012) 67:217-26. doi: 10.1111/j.1398-9995.2011.02745.x

116. Aasbjerg K, Backer V, Lund G, Holm J, Nielsen NC, Holse M, et al. Immunological comparison of allergen immunotherapy tablet treatment and subcutaneous immunotherapy against grass allergy. Clin Exp Allergy (2014) 44:417-28.

117. Shamji MH, Layhadi JA, Scadding GW, Cheung DK, Calderon MA, Turka LA, et al. Basophil expression of diamine oxidase: a novel biomarker of allergen immunotherapy response. J Allergy Clin Immunol. (2015) 135:91321 e9. doi: 10.1016/j.jaci.2014.09.049

118. Mosges R, Kasche EM, Raskopf E, Singh J, Sohlich L, Astvatsatourov A, et al. A randomized, double-blind, placebo-controlled, dose-finding trial with Lolium perenne peptide immunotherapy. Allergy (2018) 73:896-904. doi: $10.1111 /$ all. 13358 
119. Shamji MH, Ceuppens J, Bachert C, Hellings P, Placier G, Thirion G, et al. Lolium perenne peptides for treatment of grass pollen allergy: a randomized, double-blind, placebo-controlled clinical trial. J Allergy Clin Immunol. (2018) 141:448-51. doi: 10.1016/j.jaci.2017.09.013

120. Schroeder JT, Bieneman AP, Chichester KL, Hamilton RG, Xiao H, Saini SS, et al. Decreases in human dendritic cell-dependent $\mathrm{T}(\mathrm{H}) 2$-like responses after acute in vivo IgE neutralization. J Allergy Clin Immunol. (2010) 125:896-901 e6. doi: 10.1016/j.jaci.2009.10.021

121. Noga O, Hanf G, Kunkel G. Immunological and clinical changes in allergic asthmatics following treatment with omalizumab. Int Arch Allergy Immunol. (2003) 131:46-52. doi: 10.1159/000070434

122. Djukanovic R, Wilson SJ, Kraft M, Jarjour NN, Steel M, Chung KF, et al. Effects of treatment with anti-immunoglobulin E antibody omalizumab on airway inflammation in allergic asthma. Am J Respir Crit Care Med. (2004) 170:583-93. doi: 10.1164/rccm.200312-16510C

123. Ong YE, Menzies-Gow A, Barkans J, Benyahia F, Ou TT, Ying S, et al. AntiIgE (omalizumab) inhibits late-phase reactions and inflammatory cells after repeat skin allergen challenge. J Allergy Clin Immunol. (2005) 116:558-64. doi: 10.1016/j.jaci.2005.05.035

124. Klunker S, Saggar LR, Seyfert-Margolis V, Asare AL, Casale TB, Durham SR, et al. Combination treatment with omalizumab and rush immunotherapy for ragweed-induced allergic rhinitis: inhibition of $\operatorname{IgE}$ facilitated allergen binding. J Allergy Clin Immunol. (2007) 120:688-95. doi: 10.1016/j.jaci.2007.05.034

125. Shamji MH, Wilcock LK, Wachholz PA, Dearman RJ, Kimber I, Wurtzen PA, et al. The IgE-facilitated allergen binding (FAB) assay: validation of a novel flow-cytometric based method for the detection of inhibitory antibody responses. J Immunol Methods (2006) 317:71-9. doi: 10.1016/j.jim.2006.09.004

126. Shamji MH, Francis JN, Wurtzen PA, Lund K, Durham SR, Till SJ. Cellfree detection of allergen-IgE cross-linking with immobilized phase CD23: inhibition by blocking antibody responses after immunotherapy. J Allergy Clin Immunol. (2013) 132:1003-5 e1-4. doi: 10.1016/j.jaci.2013.05.025

127. Arzt L, Bokanovic D, Schrautzer C, Laipold K, Mobs C, Pfutzner W, et al. Immunological differences between insect venom-allergic patients with and without immunotherapy and asymptomatically sensitized subjects. Allergy (2018) 73:1223-31. doi: 10.1111/all.13368

128. Pennington LF, Tarchevskaya S, Brigger D, Sathiyamoorthy K, Graham MT, Nadeau KC, et al. Structural basis of omalizumab therapy and omalizumab-mediated IgE exchange. Nat Commun. (2016) 7:11610. doi: $10.1038 /$ ncomms 11610

129. Selb R, Eckl-Dorna J, Twaroch TE, Lupinek C, Teufelberger A, Hofer G, et al. Critical and direct involvement of the CD23 stalk region in $\operatorname{IgE}$ binding. J Allergy Clin Immunol. (2017) 139:281-9 e5. doi: 10.1016/j.jaci.2016. 04.015

130. Milgrom H, Fick RB, Jr, Su JQ, Reimann JD, Bush RK, Watrous ML, et al. Treatment of allergic asthma with monoclonal anti-IgE antibody. rhuMAbE25 Study Group. N Engl J Med. (1999) 341:1966-73.

131. Busse W, Corren J, Lanier BQ, McAlary M, Fowler-Taylor A, Cioppa GD, et al. Omalizumab, anti-IgE recombinant humanized monoclonal antibody, for the treatment of severe allergic asthma. J Allergy Clin Immunol. (2001) 108:184-90. doi: 10.1067/mai.2001.117880

132. Eckl-Dorna J. Omalizumab's impact on total and allergen-specific IgE levels: a polyclonal story. Int Arch Allergy Immunol. (2016) 169:69-70. doi: $10.1159 / 000444998$

133. Palomares O, Akdis M, Martín-Fontecha M, Akdis CA. Mechanism of immune regulation in allergic diseases: the role of regularory $\mathrm{T}$ and $\mathrm{B}$ cells. Immunol Rev. (2017) 278:219-36. doi: 10.1111/imr.12555

134. Van de Veen W, Stanic B, Yaman G, Wawrzyniak M, Söllner S, Akdis $\mathrm{DG}$, et al. IgG4 production is confined to human IL-10-producing regulatory B cells that suppress antigen-specific immune responses. J Allergy Clin Immunol. (2013) 131:1204-12. doi: 10.1016/j.jaci.2013. 01.014

Conflict of Interest Statement: RV has received research grants from Biomay AG and Viravaxx, Vienna, Austria and serves as a consultant for these companies.

The remaining authors declare that the research was conducted in the absence of any commercial or financial relationships that could be construed as a potential conflict of interest.

Copyright (c) 2019 Eckl-Dorna, Villazala-Merino, Linhart, Karaulov, Zhernov, Khaitov, Niederberger-Leppin and Valenta. This is an open-access article distributed under the terms of the Creative Commons Attribution License (CC BY). The use, distribution or reproduction in other forums is permitted, provided the original author(s) and the copyright owner(s) are credited and that the original publication in this journal is cited, in accordance with accepted academic practice. No use, distribution or reproduction is permitted which does not comply with these terms. 